\title{
Selective Excitation of Subtypes of Neocortical Interneurons by Nicotinic Receptors
}

\author{
James T. Porter, Bruno Cauli, Keisuke Tsuzuki, Bertrand Lambolez, Jean Rossier, and Etienne Audinat \\ Neurobiologie et Diversité Cellulaire, Centre National de la Recherche Scientifique, Unité Mixte de Recherche 7637, Ecole \\ Supérieure de Physique et de Chimie Industrielles, 75231 Paris Cedex 05, France
}

The cellular mechanisms by which neuronal nicotinic cholinergic receptors influence many aspects of physiology and pathology in the neocortex remain primarily unknown. Whole-cell recordings and single-cell reverse transcription (RT)-PCR were combined to analyze the effect of nicotinic receptor agonists on different types of neurons in acute slices of rat neocortex. Nicotinic receptor agonists had no effect on pyramidal neurons and on most types of interneurons, including parvalbuminexpressing fast spiking interneurons and somatostatinexpressing interneurons, but selectively excited a subpopulation of interneurons coexpressing the neuropeptides vasoactive intestinal peptide (VIP) and cholecystokinin. This excitation persisted in the presence of glutamate, GABA, and muscarinic receptor antagonists and in the presence of tetrodotoxin and low extracellular calcium, suggesting that the depolarization was mediated through the direct activation of postsynaptic nicotinic receptors. The responses were blocked by the nico-

Nicotinic receptors are implicated in many important functions of the mammalian neocortex, including memory formation (Granon et al., 1995) and neuronal regulation of regional cerebral blood flow (Gitelman and Prohovnik, 1992; Uchida et al., 1997), as well as cortical pathologies such as Alzheimer's disease (Whitehouse et al., 1988; Newhouse et al., 1997), epilepsy (Steinlein et al., 1995), and Tourette's syndrome (Sanberg et al., 1997, 1998). The cellular basis for the effects of nicotinic receptor stimulation is currently unknown but lies within its effects on the complex interactions between the excitatory glutamatergic pyramidal neurons and the inhibitory interneurons.

A variety of different neuronal nicotinic receptor subunits have been cloned and named $\alpha 2-\alpha 9$ and $\beta 2-\beta 4$ (Elgoyhen et al., 1994; Le Novere and Changeux, 1995). Classically, two broad subfamilies of nicotinic receptors have been characterized in neurons according to their sensitivity to $\alpha$-bungarotoxin. Subunits $\alpha 7$ and $\alpha 8$ form a family of $\alpha$-bungarotoxin-sensitive channels (Couturier et al., 1990), whereas subunits $\alpha 2-\alpha 6$ combine with subunits

\footnotetext{
Received Jan. 19, 1999; revised March 15, 1999; accepted April 12, 1999.

This work was supported by the Centre National de la Recherche Scientifique and European Union Biotech Grants 960382 and 960589. J.T.P. was supported by a Human Frontier Science Program Organization fellowship. We thank Serge Charpak and Shaul Hestrin for insightful discussions, Samia Ben Ammou for technical assistance, and Elodie Christophe for her help during some experiments.

Correspondence should be addressed to Dr. Etienne Audinat, Neurobiologie et Diversité Cellulaire, Centre National de la Recherche Scientifique, Unité Mixte de Recherche 7637, Ecole Supérieure de Physique et de Chimie Industrielles, 10 rue Vauquelin, 75231 Paris Cedex 05, France.

Dr. Porter's present address: Department of Anatomy, Box 9128, West Virginia University, Morgantown, WV 26506-9128.

Copyright (C) 1999 Society for Neuroscience 0270-6474/99/195228-08\$05.00/0
}

tinic receptor antagonists dihydro- $\beta$-erythroidine and mecamylamine and persisted in the presence of the $\alpha 7$ selective nicotinic receptor antagonist methyllycaconitine, suggesting that the involved nicotinic receptors lacked the $\alpha 7$ subunit. Single-cell RT-PCR analysis indicated that the majority of the interneurons that responded to nicotinic stimulation coexpressed the $\alpha 4, \alpha 5$, and $\beta 2$ nicotinic receptor subunits. Therefore, these results provide a role for non- $\alpha 7$ nicotinic receptors in the selective excitation of a subpopulation of neocortical interneurons. Because the neocortical interneurons expressing VIP have been proposed previously to regulate regional cortical blood flow and metabolism, these results also provide a cellular basis for the neuronal regulation of cortical blood flow mediated by acetylcholine.

Key words: single-cell PCR; neuropeptides; calcium-binding proteins; methyllycaconitine; dihydro- $\beta$-erythroidine; acetylcholine; mecamylamine $\beta 2-\beta 4$ to produce $\alpha$-bungarotoxin-insensitive channels (Sargent, 1993). In situ hybridization studies indicate that only $\alpha 3, \alpha 4, \alpha 5$, $\alpha 7$, and $\beta 2$ subunits are expressed in the rat neocortex (Wada et al., 1989, 1990; Lena and Changeux, 1997). In this structure as in other brain areas, functional studies have suggested that $\alpha 7$ nicotinic receptors present on the axonal terminals of excitatory neurons modulate the release of glutamate (Vidal and Changeux, 1993; McGehee et al., 1995; Gray et al., 1996; Role and Berg, 1996; Gil et al., 1997). In contrast, the functional role of non- $\alpha 7$ nicotinic receptors, which are also widely expressed in the neocortex, is still unknown (Sivilotti and Colquhoun, 1995). In rodents, neocortical pyramidal cells are not directly depolarized by nicotinic agonists (Vidal and Changeux, 1993; Gil et al., 1997) (but see Roerig et al., 1997), suggesting that these non- $\alpha 7$ nicotinic receptors may be expressed by interneurons. Despite the general use of GABA as a neurotransmitter, neocortical interneurons are widely heterogeneous in terms of morphological, physiological, and biochemical characteristics (McCormick et al., 1985; Kubota et al., 1994; Thomson and Deuchars, 1994; Kawaguchi, 1995; Angulo et al., 1997; Cauli et al., 1997; Porter et al., 1998; Xiang et al., 1998). Therefore, the stimulation of different types of neocortical interneurons can produce a large variety of functional outcomes. In the present work, we examined pyramidal and nonpyramidal neurons of rat neocortical slices for responsiveness to nicotinic receptor agonists to determine the neuronal types excited by nicotinic receptor stimulation and the nicotinic receptors involved. Responsive neurons were then identified using electrophysiological and molecular criteria. The results indicate that nicotinic receptor stimulation in the neocortex selec- 
tively excites an interneuronal population coexpressing vasoactive intestinal peptide (VIP) and cholecystokinin (CCK) through the activation of nicotinic receptors containing $\alpha 4, \alpha 5$, and $\beta 2$ subunits.

\section{MATERIALS AND METHODS}

The procedures for preparation of the brain slices and whole-cell recordings of visualized neurons have been described previously (Cauli et al., 1997; Porter et al., 1998). In brief, Wistar rats (13-36 postnatal days) were anesthetized with a mixture of xylazine $(14 \mathrm{mg} / \mathrm{kg})$ and ketamine $(65 \mathrm{mg} / \mathrm{kg})$ and killed by decapitation. Parasagittal sections $(300-\mu \mathrm{m}-$ thick) of cerebral cortex were prepared. The slices were incubated at room temperature $\left(20-25^{\circ} \mathrm{C}\right.$ ) in artificial CSF (ACSF) containing (in mM): $\mathrm{NaCl} 121.0, \mathrm{KCl} 2.5, \mathrm{NaH}_{2} \mathrm{PO}_{4} 1.25, \mathrm{CaCl}_{2} 2, \mathrm{MgCl}_{2} 1, \mathrm{NaHCO}_{3}$ 26 , glucose 20 , and pyruvate 5 , which was bubbled with a mixture of $95 \%$ $\mathrm{O}_{2}$ and $5 \% \mathrm{CO}_{2}$. Slices were transferred to a chamber and perfused at $1-2 \mathrm{ml} / \mathrm{min}$ with $\mathrm{ACSF}\left(34^{\circ} \mathrm{C}\right)$.

Neurons were recorded in layers II, III, and V of the motor cortex using the whole-cell configuration of the patch-clamp technique. Patch pipettes (3-5 M $\Omega$ ), pulled from borosilicate glass, were filled with $8 \mu \mathrm{l}$ of internal solution containing (in $\mathrm{mM}$ ): $\mathrm{K}$ gluconate $144, \mathrm{MgCl}_{2} 3$, EGTA 0.2, and HEPES 10, pH 7.2 (285/295 mOsm). All membrane potential values obtained with this solution were corrected for the junction potential of $-11 \mathrm{mV}$. The $I-V$ relationship of the 1,1-dimethyl-4-phenylpiperazinium iodide (DMPP)-induced currents was measured with an internal solution containing (in mM): CsGluconate 117, CsCl 12, HEPES 10, EGTA 0.2 , and $\mathrm{MgCl}_{2} 3$, pH 7.2. The firing behavior of the neurons was tested by applying depolarizing current pulses at a membrane potential of $-71 \mathrm{mV}$. Action potential discharges were recorded using the current-clamp fast mode of the Axopatch 200A amplifier (Axon instruments, Foster City, CA). Only cells with a resting membrane potential more negative than $-50 \mathrm{mV}$ were analyzed. In current-clamp and voltage-clamp experiments, the signals were filtered, respectively, at 5 and $1 \mathrm{kHz}$, digitized at $10-20 \mathrm{kHz}$, saved to a personal computer, and analyzed off-line with Acquis1 software (Gérard Sadoc, Gif/Yvette, France). The series resistance was not compensated but was monitored throughout the experiments. DMPP $(100-500 \mu \mathrm{M})$ and acetylcholine $(100 \mu \mathrm{M})$ in ACSF were applied by pressure from a large pipette onto the recorded neuron. All reported values are expressed as the mean \pm SD of the mean. Antagonists were added directly to the bathing solution.

At the end of the recording, the content of the cell was aspirated under visual control into the recording pipette and expelled into a test tube, where reverse transcription (RT) was performed in a final volume of 10 $\mu l$ (Lambolez et al., 1992). The two steps of multiplex PCR were performed essentially as described previously (Ruano et al., 1995). The cDNAs present in $10 \mu \mathrm{l}$ of the reverse transcription reaction were first amplified simultaneously using the primer pairs described previously (Cauli et al., 1997). Taq polymerase (2.5 U; Perkin-Elmer, Emeryville, CA) and $10 \mathrm{pmol}$ of each of the primers were added to the buffer supplied by the manufacturer (final volume of $100 \mu \mathrm{l})$, and 20 cycles $\left(94^{\circ} \mathrm{C}, 30 \mathrm{sec}\right.$; $60^{\circ} \mathrm{C}, 30 \mathrm{sec} ; 72^{\circ} \mathrm{C}, 35 \mathrm{sec}$ ) of PCR were run. Second rounds of PCR were then performed using $2 \mu \mathrm{l}$ of the first PCR product as template. In this second round, each cDNA was individually amplified using its specific primer pair by performing 35 PCR cycles. Each individual PCR reaction $(10 \mu \mathrm{l})$ was then run on a $1.5 \%$ agarose gel using $\Phi \times 174$ digested by HaeIII as molecular weight markers and stained with ethidium bromide. To identify the PCR products, PCR-generated fragments obtained from each cell were transferred onto Hybond $\mathrm{N}^{+}$(Amersham, Arlington Heights, IL). The Southern blots were probed with specific oligonucleotides (Cauli et al., 1997) using the ECL $3^{\prime}$-oligo labeling and detection kit (Amersham) according to the manufacturer's instructions.

To amplify the neuronal nicotinic receptor subunits by RT-multiplex PCR, the two steps of PCR were performed as described above using the following sets of primers (from $5^{\prime}$ to $3^{\prime}$, the numbers in brackets indicate the initial and final positions of the PCR primers): $\alpha 2$ (GenBank accession number L10077): sense [158-175], antisense [440-457]; $\alpha 3$ (GenBank accession number L32621): sense [44-66], antisense [242-264]; $\alpha 4$ (GenBank accession number L31620): sense [347-366], antisense [591611]; $\alpha 5$ (GenBank accession number J05231): sense [1203-1222], antisense [1470-1493]; $\alpha 6$ (GenBank accession number L08227): sense [127148], antisense [474-493]; $\alpha 7$ (GenBank accession number L31619): sense [36-53], antisense [385-404]; $\beta 2$ (GenBank accession number L31622): sense [197-215], antisense [504-522]; $\beta 3$ (GenBank accession number J04636): sense [220-239], antisense [539-559]; and $\beta 4$ : sense
CTGCTATGAAGGGGTGAACATT, antisense CCGTCCTCCGTCC TGGG.

The predicted sizes of the PCR products were (in base pairs) $\alpha 2$ (300), $\alpha 3$ (221), $\alpha 4$ (265), $\alpha 5$ (291), $\alpha 6$ (367), $\alpha 7$ (369), $\beta 2$ (326), $\beta 3$ (340), and $\beta 4$ (347). The efficiency of this RT-multiplex PCR protocol was tested on $2 \mathrm{ng}$ of whole-brain total RNA (see Fig. $4 A$ ). The identity of the PCR-generated fragments were confirmed by restriction analysis (data not shown) and by Southern blot analysis (data not shown) using the following set of specific sense oligoprobes labeled with AlkPhos Direct labeling and detection kit (Amersham) according to manufacturer's instructions (from $5^{\prime}$ to $3^{\prime}$, the numbers in brackets indicate the initial and final positions of the oligoprobes): $\alpha 3$, [112-132]; $\alpha 4$, [ 511-532]; $\alpha 5$, [ 1294-1315]; $\alpha 7$, [ 123-134]; and $\beta 2$, [ 477-468]. Genomic DNA amplifications, which sometimes occurred when the nucleus was harvested, could be easily differentiated from cDNA amplification by a size criterion. Indeed, for each primer pair, the sense and antisense primers were positioned on two different exons.

6-Cyano-7-nitroquinoxaline-2,3-dione (CNQX) and 2-amino-5phosphonovalerate (D-APV) were obtained from Tocris Cookson (Bristol, UK). Picrotoxin, atropine, mecamylamine, and DMPP were obtained from Sigma (St Louis, MO). Acetylcholine, methyllycaconitine (MLA), and dihydro- $\beta$-erythroidine were obtained from Research Biochemicals (Natick, MA).

\section{RESULTS}

\section{Selective nicotinic excitation of subtypes of neocortical interneurons}

To identify the neuronal targets of nicotine, pyramidal neurons and interneurons in rat neocortical slices were first visually identified with infrared video microscopy, recorded in whole-cell configuration, and classified as irregular-spiking (IS) interneurons, regular-spiking nonpyramidal (RSNP) neurons, fast-spiking (FS) interneurons, or pyramidal neurons according to their action potential firing behavior (McCormick et al., 1985; Kawaguchi, 1995; Cauli et al., 1997) (Fig. 1A-E, left column). Then, the sensitivity of these different types of neocortical neurons to the local pressure application of the selective nicotinic cholinergic receptor agonist DMPP (100-500 $\mu \mathrm{M})$ was tested.

In response to depolarizing pulses of current, IS interneurons typically exhibited an initial burst of action potentials, followed by discharges of action potentials at an irregular frequency (Fig. $1 A$, left). The majority of IS interneurons (77\%; 17 of 22) were depolarized by DMPP sufficiently to reach action potential threshold and fired bursts of spikes (Fig. 1A, right). As shown in the example, some IS interneurons ( 4 of 22 neurons) exhibited low-threshold $\mathrm{Ca}^{2+}$ spikes at the end of a hyperpolarizing current pulse (Fig. $1 A$, arrowhead).

RSNP neurons exhibited continuous discharges of action potentials with varying amounts of frequency adaptation accompanied by decreases in action potential amplitude (Fig. 1B,C). Within our sample of RSNP neurons, 63 of 100 interneurons responded to the nicotinic agonist (Fig. 1B, right), whereas $37 \%$ did not respond (Fig. 1C, right). The majority of the DMPPsensitive RSNP interneurons (94\%; 59 of 63) did not exhibit low-threshold $\mathrm{Ca}^{2+}$ spikes.

FS interneurons were characterized by their fast action potentials discharged at high frequencies with little frequency adaptation or decrease in action potential amplitude (Fig. 1D, left). The majority (92\%; 12 of 13) of FS interneurons were not affected by the application of DMPP (Fig. 1D, right).

The majority of these interneurons were recorded in layers II/III of the motor cortex. Twenty-two interneurons (7 FS and 15 RSNP neurons) were analyzed in layer $\mathrm{V}$, among which only three RSNP neurons responded to DMPP.

Pyramidal neurons typically fired action potentials of longer duration, lower frequency, and with more frequency adaptation 

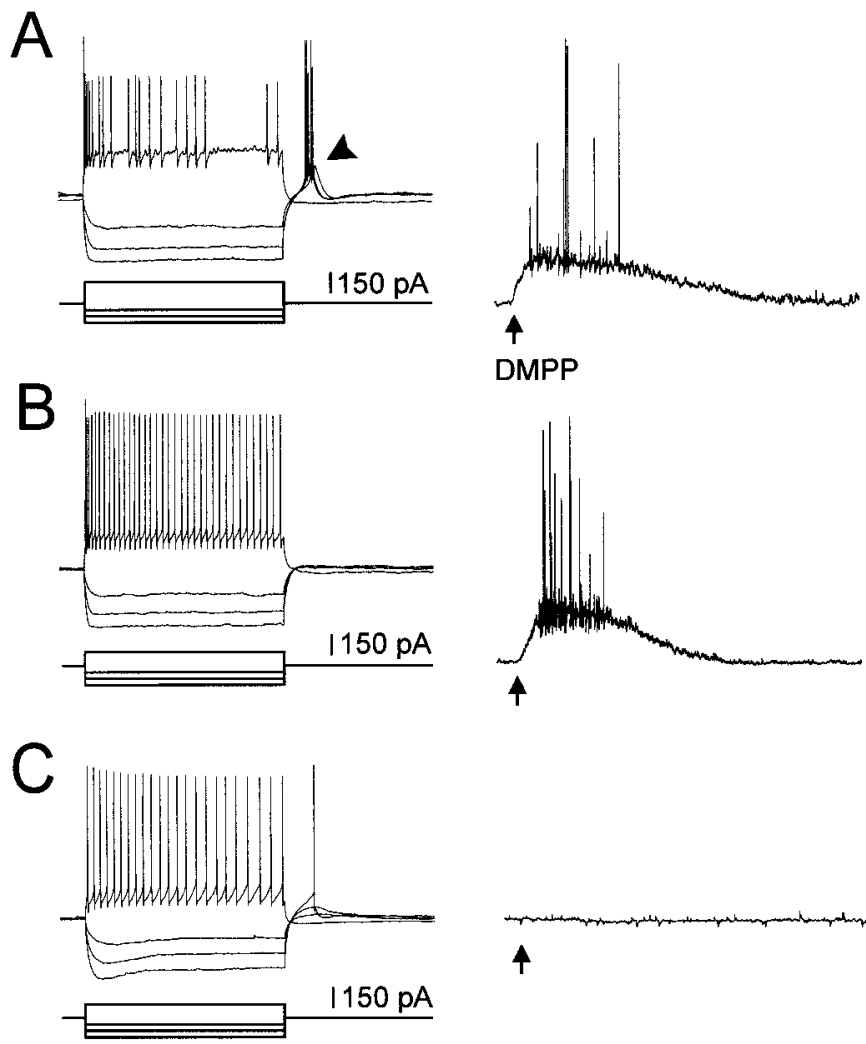

D
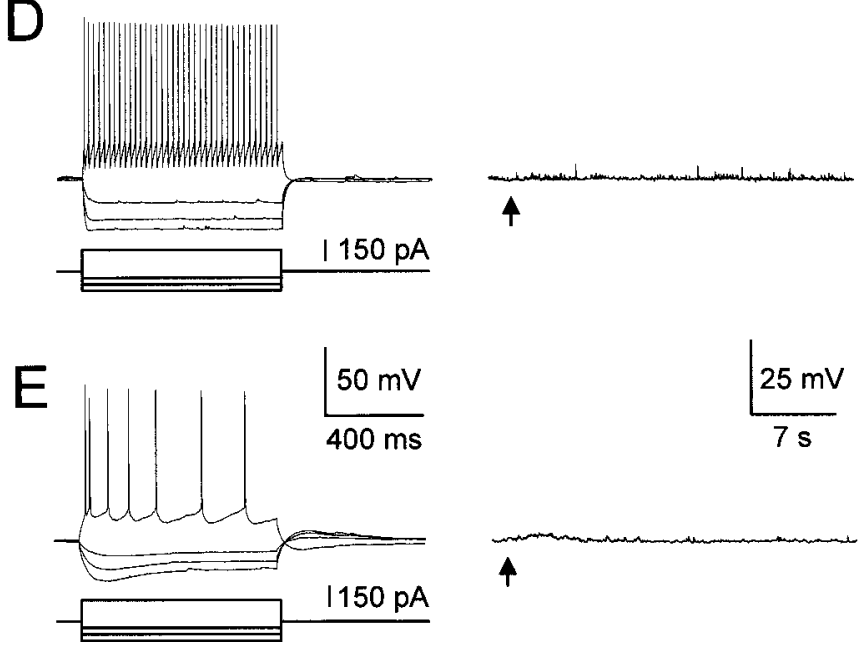

Figure 1. Distinct electrophysiologically identified types of neocortical interneurons are excited by nicotinic receptor stimulation. The currentclamp recordings shown in the left column of each panel illustrate the voltage responses exhibited by an IS interneuron $(A)$, two RSNP interneurons $(B, C)$, an FS interneuron $(D)$, and a pyramidal neuron $(E)$ in response to hyperpolarizing and depolarizing current injections. The arrowhead in $A$ denotes the presence of low-threshold $\mathrm{Ca}^{2+}$ spikes. In the right column of each panel are the responses of the same five neurons to the local pressure application of $100 \mu \mathrm{M}$ DMPP $(1 \mathrm{sec})$. Action potentials in the right column are truncated because of the sampling rate. The arrows indicate the beginning of the DMPP applications. The membrane potentials were adjusted to $-71 \mathrm{mV}$.

than interneurons (Fig. 1E, left). Consistent with previous reports (Vidal and Changeux, 1993; Gil et al., 1997), none of the pyramidal neurons $(n=12)$ recorded in layers II/III and V were directly depolarized by the application of DMPP. Although,
DMPP induced a slight depolarization of some pyramidal neurons, these responses were blocked by glutamatergic and GABAergic receptor antagonists (see below), indicating that they were a result of presynaptic effects of DMPP (Fig. 1E, right). These results indicate that IS interneurons and a subpopulation of RSNP neurons are selectively activated by nicotinic stimulation.

\section{Neocortical interneurons excited by nicotinic receptor stimulation express VIP and CCK}

Neocortical interneurons can also be classified by the presence of the three calcium-binding proteins calretinin, calbindin, and parvalbumin, and the four neuropeptides VIP, somatostatin, CCK, and neuropeptide Y (Kubota et al., 1994; Kawaguchi, 1995; Cauli et al., 1997). Ninety-six interneurons (12 FS, 13 IS, and 71 RSNP neurons) that had been tested for sensitivity to DMPP were analyzed by single-cell RT-PCR to detect the presence of mRNAs encoding the above calcium binding proteins and neuropeptides, as well as the two isoforms of the GABA-synthesizing enzyme, glutamic acid decarboxylase (GAD65 and GAD67) (Cauli et al., 1997). The agarose gels of the RT-PCR products for the two RSNP neurons described in Figure $1, B$ and $C$, are shown in Figure 2, $A$ and $B$, respectively. GAD65 and GAD67 mRNAs were detected in both interneurons. The RSNP neuron that was excited by DMPP also expressed VIP, CCK, and calretinin mRNAs (Fig. 2A). In contrast, the mRNAs for somatostatin, neuropeptide $\mathrm{Y}$, calbindin, and calretinin were detected in the DMPP-insensitive neuron (Fig. 2B). All 96 neocortical interneurons examined expressed one or both isoforms of GAD, indicating that they were inhibitory interneurons. Eighty-one of the interneurons analyzed by single-cell RT-PCR were in layers II/ III, and 15 interneurons were in layer V. In the population of DMPP-sensitive interneurons (9 IS, 1 FS, and 48 RSNP neurons), the most widely detected markers were VIP and CCK, which were expressed, respectively, by 51 and 45 of the 58 interneurons (Fig. 2C). VIP and CCK were coexpressed in 41 of the interneurons. In contrast, VIP and CCK were only detected in 8 and 15 of the 38 DMPP-insensitive interneurons (Fig. 2D). The majority of the insensitive interneurons expressed calbindin (26 neurons) and somatostatin (27 neurons). Therefore, the majority of the two populations of interneurons excited by nicotinic agonists, IS neurons and a fraction of RSNP neurons, coexpressed VIP and CCK.

\section{Direct stimulation of somatodendritic nicotinic receptors}

To confirm that the responses to DMPP were caused by the direct activation of the interneurons and not by presynaptic effects of nicotinic receptor stimulation, the AMPA/kainate receptor antagonist CNQX $(10 \mu \mathrm{M})$, the NMDA receptor antagonist D-APV $(50 \mu \mathrm{M})$, the $\mathrm{GABA}_{\mathrm{A}}$ receptor antagonist picrotoxin $(100 \mu \mathrm{M})$, and the muscarinic receptor antagonist atropine $(5 \mu \mathrm{M})$ were added to the bathing solution. In the presence these receptor antagonists, $100 \mu \mathrm{M}$ DMPP still depolarized neocortical interneurons sufficiently to discharge action potentials (data not shown) and, in voltage-clamp experiments, the currents induced by DMPP exhibited an inward rectification at depolarized potentials, with no current being detected at positive potentials $(n=5)$ (Fig. 3A). The DMPP-mediated currents also persisted when synaptic transmission was blocked with a bathing solution containing $0.5 \mathrm{mM} \mathrm{Ca}^{2+}, 4 \mathrm{mM} \mathrm{Mg}^{2+}$, and $1 \mu \mathrm{M}$ tetrodotoxin $(n=3$; data not shown). These results indicate that the nicotinic receptor agonist directly activated the neocortical interneurons, probably through the stimulation of somatodendritic nicotinic receptors. 

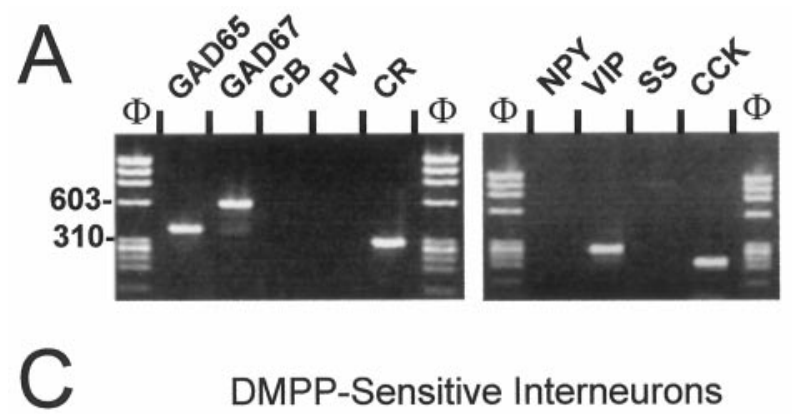

DMPP-Sensitive Interneurons

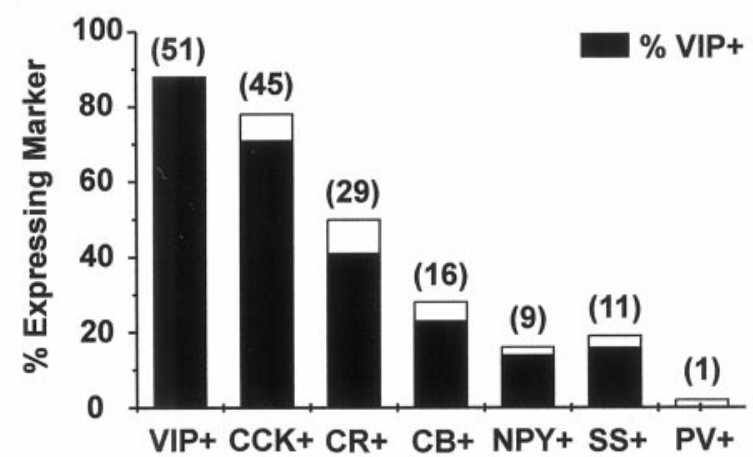

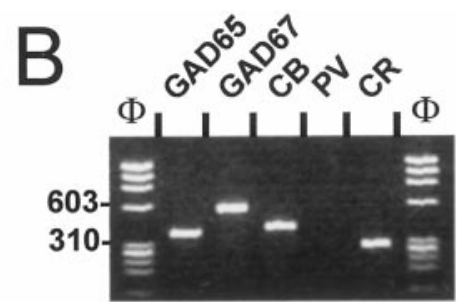

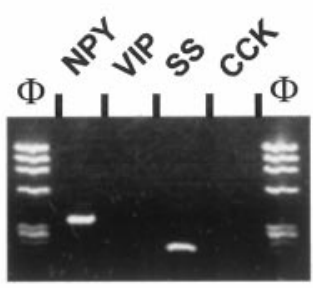

D

DMPP-Insensitive Interneurons

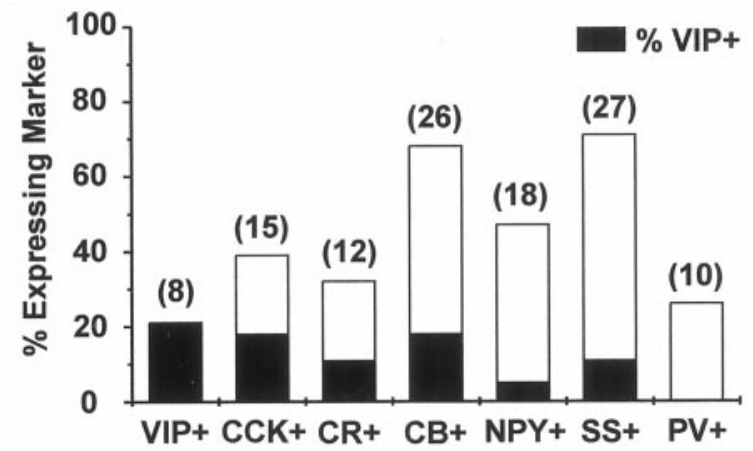

Figure 2. The majority of neocortical interneurons excited by nicotinic receptor stimulation coexpress VIP and CCK. $A, B$, Agarose gels of the PCR products obtained from the two RSNP interneurons described in Figure 1, $B$ and $C$, respectively. The two interneurons expressed GAD65, GAD67, and calretinin (CR) mRNAs. The cell shown in $A$ also expressed VIP and CCK, whereas the cell in $B$ expressed calbindin $(C B)$, neuropeptide Y (NPY), and somatostatin $(S S)$. Neither of these two cells expressed parvalbumin $(P V)$. The identity of all products was confirmed by Southern blot analysis. $C, D$, These graphs illustrate the percentage of DMPP-sensitive $(n=58)$ and DMPP-insensitive $(n=38)$ interneurons that expressed each of the markers detected by single-cell RT-PCR. The number of interneurons in each group is given in parentheses above the bars. The filled portions indicate the fraction of interneurons in each group that coexpressed VIP.

\section{Interneuronal responses are mediated by non- $\alpha 7$ nicotinic receptors}

Because neuronal nicotinic responses mediated by receptors containing and lacking the $\alpha 7$ subunit are pharmacologically distinct, we examined the sensitivity of the nicotinic responses to the nicotinic receptor antagonists dihydro- $\beta$-erythroidine, mecamylamine, and MLA. Both dihydro- $\beta$-erythroidine and mecamylamine selectively block non- $\alpha 7$ nicotinic receptor, whereas MLA selectively blocks $\alpha 7$ nicotinic receptors (Alkondon and Albuquerque, 1993; Palma et al., 1996; Zoli et al., 1998). Perfusion of either dihydro$\beta$-erythroidine $(500 \mathrm{nM})$ or mecamylamine $(2 \mu \mathrm{M})$ antagonized the currents mediated by $100 \mu \mathrm{M}$ DMPP by an average of $80 \pm 17(n=$ 17) and $90 \pm 7 \%(n=14)$, respectively (Fig. 3B). In contrast, perfusion of MLA (10 nM) reduced the currents by only $30 \pm 5 \%$ $(n=3)$. The remaining MLA-insensitive currents were sensitive to $500 \mathrm{~nm}$ dihydro- $\beta$-erythroidine ( $84 \pm 16 \%$ block; $n=3$ ) (Fig. $3 C)$. The endogenous nicotinic receptor agonist acetylcholine $(100 \mu \mathrm{M})$ also activated neocortical interneurons $(n=6)$, and the pharmacological profile of these responses was similar to that of DMPPinduced currents (Fig. $3 C$ ). On the average, $86 \pm 8 \%$ of the currents evoked by acetylcholine were reversibly antagonized by $500 \mathrm{~nm}$ dihydro- $\beta$-erythroidine $(n=5)$ (Fig. $3 D)$, whereas $10 \mathrm{~nm}$ MLA reduced the currents by only $22 \pm 2 \%(n=3)$. These results indicated that DMPP and acetylcholine directly excite neocortical interneurons mainly through the activation of nicotinic receptors lacking the $\alpha 7$ subunit.

\section{Nicotinic receptors subunits expressed by responsive interneurons}

The nicotinic receptor subunits expressed in the rat neocortex are $\alpha 3, \alpha 4, \alpha 5, \alpha 7$ and $\beta 2$ (Wada et al., 1989, 1990). Because various combinations of these subunits have been shown to form functional non- $\alpha 7$ nicotinic receptors (Papke et al., 1989; Boulter et al., 1990; Papke, 1993; Ramirez-Latorre et al., 1996), single-cell RT-PCR was used to determine which of these subunits were expressed in 17 interneurons that responded to DMPP. Consistent with the pharmacological data, single-cell RT-PCR analysis indicated that most of the interneurons that were excited by nicotinic agonists expressed the mRNAs for $\alpha 4, \alpha 5$, and $\beta 2$ (Fig. $4 B, C$ ). In contrast, the majority (10 of 17 interneurons) of the DMPP-sensitive neocortical interneurons did not express $\alpha 7$ subunits. Consistent with in situ hybridization studies (Wada et al., 1989; 1990; Lena and Changeux, 1997), the mRNAs encoding $\alpha 2, \alpha 6, \beta 3$, and $\beta 4$ were not detected in any of the interneurons. The mRNAs encoding the nine nicotinic receptor subunits, however, could be simultaneously detected in $2 \mathrm{ng}$ of total brain RNA (Fig. 4A).

\section{DISCUSSION}

Our results demonstrate that nicotinic agonists selectively excite two types of physiologically identified neocortical interneurons, IS and RSNP interneurons, both of which coexpress VIP and CCK. Unlike presynaptic nicotinic receptors modulating glutamate release in cortical areas (McGehee et al., 1995; Gil et al., 1997), nicotinic receptors located on the soma and/or the dendrites of neocortical VIP interneurons lack the $\alpha 7$ subunit.

\section{Expression of functional non- $\alpha 7$ nicotinic receptors in the neocortex}

Previous in situ hybridization studies indicate that $\alpha 3, \alpha 4, \alpha 5, \alpha 7$, and $\beta 2$ subunits are expressed in the rat neocortex (Wada et al., 1989, 1990). The neocortical interneurons excited by nicotinic 

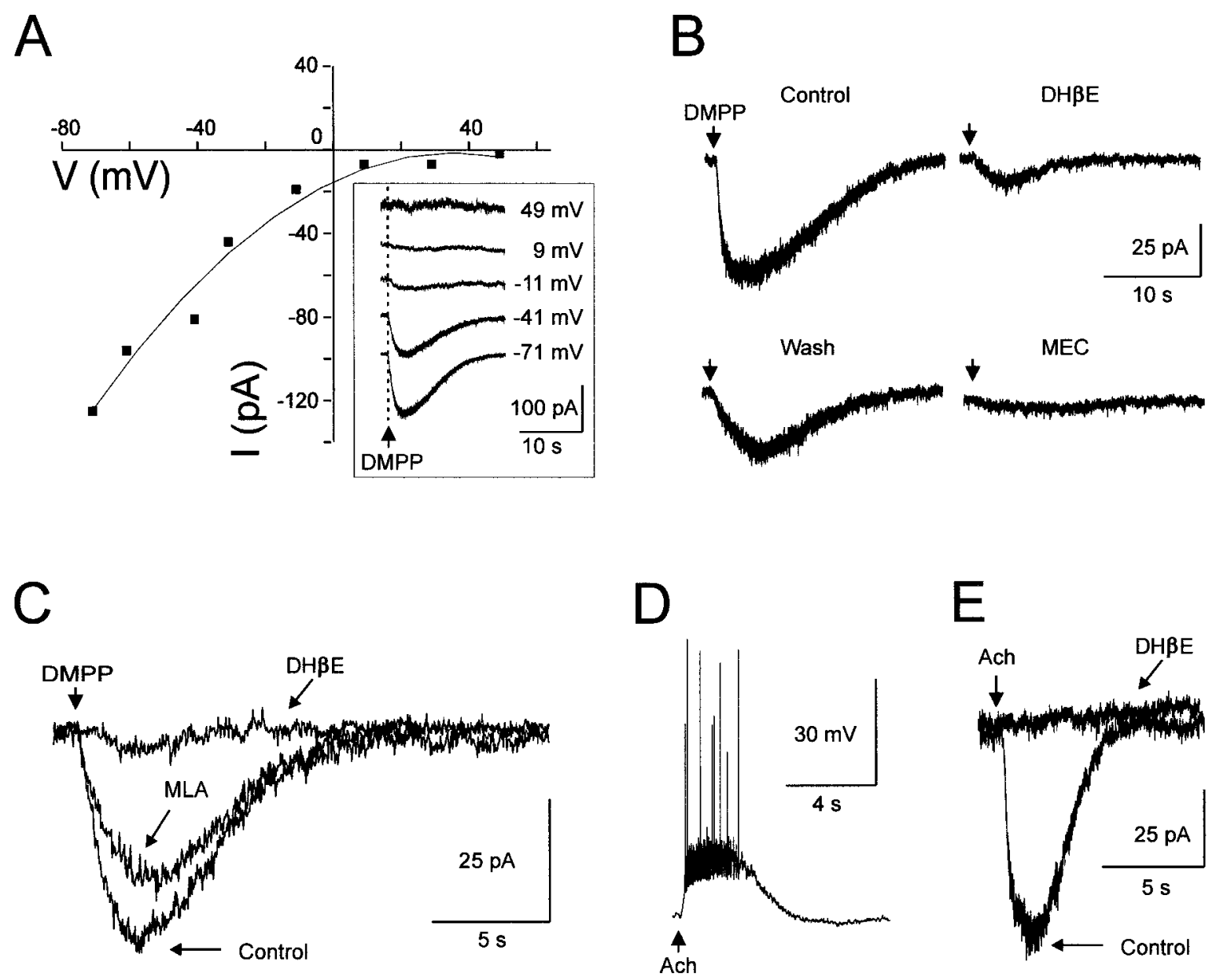

Figure 3. Rectification and pharmacology of responses to nicotinic receptor activation in neocortical interneurons. $A$, In voltage clamp, $100 \mu \mathrm{M}$ DMPP induced inward currents (inset) in an interneuron with a peak $I-V$ relationship that showed inward rectification. $B$, The currents induced by $100 \mu \mathrm{M}$ DMPP in an interneuron were antagonized by $500 \mathrm{nM}$ dihydro- $\beta$-erythroidine $(D H \beta E)$. After washing out dihydro- $\beta$-erythroidine, the DMPP-induced current partially recovered (Wash) and was almost abolished by $2 \mu \mathrm{M}$ mecamylamine (MEC). The arrows indicate the beginning of the 1 sec pressure applications of DMPP. $C$, The DMPP-induced current in a neocortical interneuron (Control) was only slightly reduced by the application of 10 nM MLA. The remaining current was almost completely abolished by $500 \mathrm{~nm}$ dihydro- $\beta$-erythroidine $(D H \beta \mathrm{E})$. $D$, In current clamp, the application of $100 \mu \mathrm{M}$ acetylcholine $(A c h)$ depolarized an interneuron and induced a discharge of action potentials. Action potentials are truncated because of the sampling rate. $E$, In the same interneuron recorded in voltage clamp, acetylcholine induced an inward current (Control, bottom trace) that was blocked by $500 \mathrm{~nm}$ dihydro- $\beta$-erythroidine $(D H \beta E$, top trace). All responses $(A-E)$ were recorded in the presence of glutamatergic, GABAergic, and muscarinic receptor antagonists (see Results).

receptor stimulation predominately expressed the mRNAs for the $\alpha 4, \alpha 5$, and $\beta 2$ subunits. Although the $\alpha 7$ subunit was detected in some of the VIPergic interneurons excited by DMPP, the majority of the responsive interneurons did not express this subunit. Accordingly, the pharmacological profile of the nicotinic responses was typical of non- $\alpha 7$ nicotinic receptors. The nicotinic currents in the neocortical interneurons were only slightly reduced by MLA, the selective antagonist of $\alpha 7$ nicotinic receptors (Palma et al., 1996). On the other hand, the responses to DMPP were blocked by dihydro- $\beta$-erythroidine and mecamylamine, two selective antagonists of non- $\alpha 7$ nicotinic receptors (Alkondon and Albuquerque, 1993; Zoli et al., 1998). Thus, the molecular and pharmacological data indicate that the nicotinic excitation of VIPergic interneurons is mediated by nicotinic receptors composed of $\alpha 4, \alpha 5$, and $\beta 2$ subunits. In heterologous expression systems, functional channels are formed by the coexpression of $\alpha 4$ and $\beta 2$ subunits (Papke et al., 1989; Boulter et al., 1990; Cooper et al., 1991; Luetje and Patrick, 1991; Papke, 1993) or by the coexpression of $\alpha 4, \alpha 5$, and $\beta 2$ subunits (Ramirez-Latorre et al.,
1996). The addition of the $\alpha 5$ subunit to channels composed of $\alpha 4$ and $\beta 2$ increases the conductance of the channels (RamirezLatorre et al., 1996). In contrast, the expression of either of the three subunits alone, the coexpression of $\alpha 4$ and $\alpha 5$ subunits, or the coexpression of $\alpha 5$ and $\beta 2$ subunits (Boulter et al., 1990; Ramirez-Latorre et al., 1996) does not form functional nicotinic receptors. Thus, the responsive interneurons apparently contain nicotinic receptors composed of $\alpha 4$ and $\beta 2$ subunits and/or $\alpha 4$, $\alpha 5$, and $\beta 2$ subunits.

\section{Selective expression of postsynaptic nicotinic receptors by interneurons in cortical areas}

Our results, together with previous observations (Vidal and Changeux, 1993; Jones and Yakel, 1997; Frazier et al., 1998; Xiang et al., 1998), suggest that somatodendritic nicotinic receptors are selectively expressed by interneurons and not by pyramidal neurons in the rat neocortex and hippocampus. There are, however, several differences in the expression of nicotinic receptors in the two structures. In the hippocampus, almost all of the 

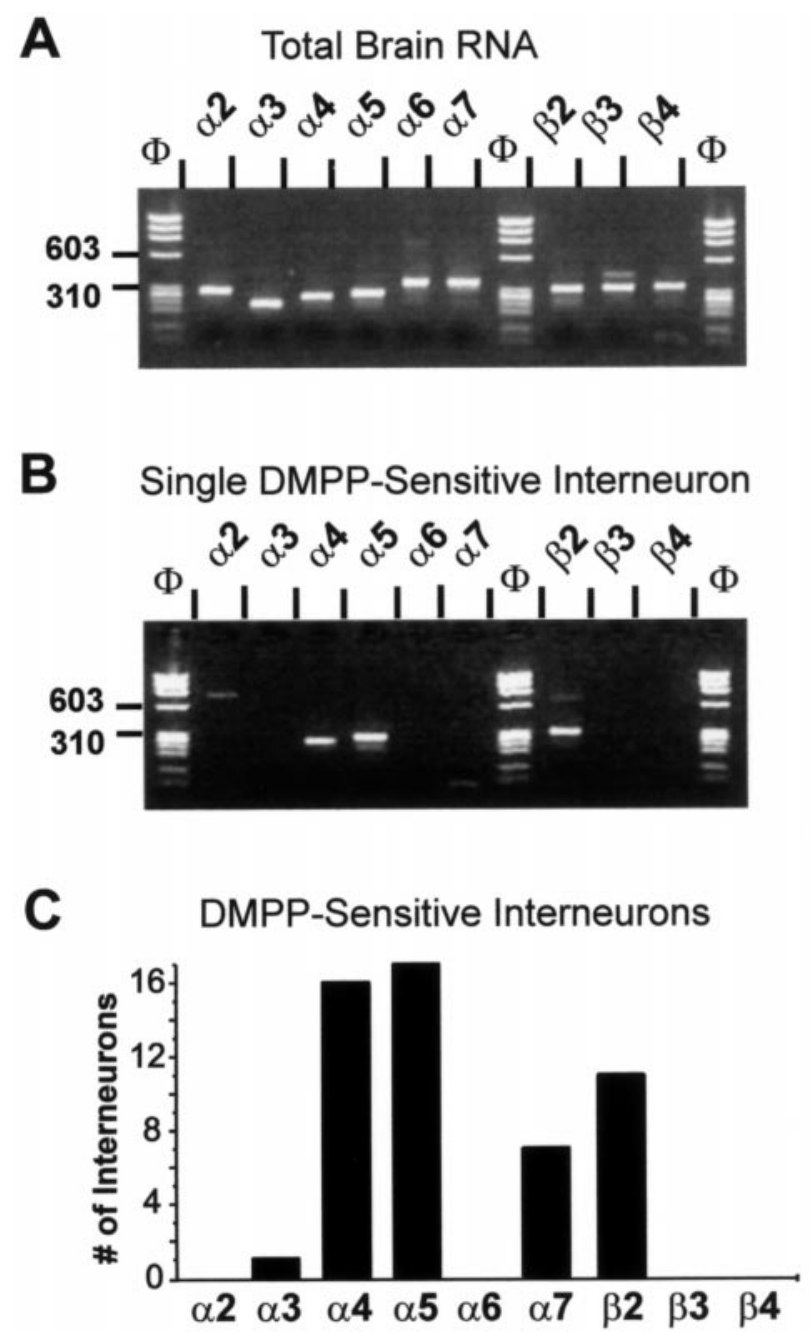

Figure 4. Nicotinic receptor subunits expressed by neocortical interneurons sensitive to DMPP. A, Agarose gel electrophoresis of the products obtained from $2 \mathrm{mg}$ of total brain RNA by an RT-PCR procedure designed to coamplify simultaneously the mRNAs encoding the $\alpha 2, \alpha 3$, $\alpha 4, \alpha 5, \alpha 6, \alpha 7, \beta 2, \beta 3$, and $\beta 4$ subunits of nicotinic receptors. All nine nicotinic receptor subunits were detected. The faint bands in the $\beta 2$ and $\beta 3$ lanes correspond to nonspecific amplifications. $B$, Agarose gel electrophoresis of the PCR products obtained from an RSNP interneuron that responded to DMPP applications in the presence of glutamatergic, GABAergic, and muscarinic receptor antagonists. Only the $\alpha 4, \alpha 5$, and $\beta 2$ subunits were detected in this interneuron. The faint and heavy bands in the $\alpha 2$ and $\beta 2$ lanes correspond to nonspecific amplifications. The identity of the PCR products was confirmed by Southern blot analysis. $C$, Number of DMPP-sensitive interneurons in which the mRNAs for the nicotinic receptor subunits were detected by single-cell RT-PCR $(n=17)$. Note that the majority of the tested interneurons expressed $\alpha 4, \alpha 5$, and $\beta 2$ subunits.

interneurons tested responded to nicotinic stimulation apparently through $\alpha 7$-containing nicotinic receptors (Jones and Yakel, 1997; Frazier et al., 1998). In contrast, in the neocortex, only VIPand CCK-expressing interneurons responded to nicotinic stimulation, and this excitation was mediated by the activation of non- $\alpha 7$ nicotinic receptors. A recent report indicates that, in the visual cortex, interneurons exhibiting low-threshold $\mathrm{Ca}^{2+}$ spikes are excited by nicotinic stimulation, whereas FS interneurons are insensitive to nicotinic stimulation (Xiang et al., 1998). Because the majority $(90 \% ; 77$ of 85$)$ of the neocortical interneurons excited by nicotinic stimulation in the present study did not exhibit low-threshold $\mathrm{Ca}^{2+}$ spikes, the presence of low-threshold $\mathrm{Ca}^{2+}$ spikes does not appear to be the best marker of nicotinicsensitive interneurons in the motor cortex. Finally, the expression of nicotinic receptors in the neocortex may differ among species, because in the ferret neocortex both pyramidal neurons and interneurons have been shown to express functional nicotinic receptors (Roerig et al., 1997).

\section{Potential implications of nicotinic receptor-mediated excitation of interneurons expressing VIP and CCK}

Nicotinic receptors are important for maintaining performance in a variety of cognitive tasks involving cortical areas (Changeux et al., 1998). In the neocortex, functional postsynaptic nicotinic receptors are selectively expressed by a subpopulation of interneurons coexpressing VIP and CCK. We and others have shown previously that VIP is expressed by subsets of bipolar and bitufted neocortical interneurons (Eckenstein and Baughman, 1984; Morrison et al., 1984; Cauli et al., 1997; Porter et al., 1998) and immunocytochemical data also indicates that CCK is often co-expressed with VIP in these interneurons (Papadopoulos et al., 1987; Kubota and Kawaguchi, 1997). Given the primarily columnarly restricted axonal arbors of interneurons expressing VIP and CCK (Hendry et al., 1983; Connor and Peters, 1984; Magistretti et al., 1984; Kawaguchi and Kubota, 1996; Porter et al., 1998), nicotinic receptor-mediated stimulation of these interneurons may provide a selective increase in the columnar inhibition involved in neocortical information processing (Xiang et al., 1998).

In addition, several lines of evidence suggest that VIPexpressing interneurons are involved in the regulation of regional cerebral blood flow and metabolism in the neocortex (Itakura et al., 1987; Yaksh et al., 1987; Magistretti, 1990). First, VIPcontaining neuronal fibers are intimately associated with the intracortical blood vessels (Eckenstein and Baughman, 1984; Chédotal et al., 1994a, 1994b). Second, the application of VIP induces a dilatation of pial arteries (Yaksh et al., 1987). Third, the injection of VIP into the cortex increase the cerebral blood flow (Itakura et al., 1987). Fourth, VIP activates glycogenolysis in neocortical slices (Magistretti et al., 1981). Therefore, the nicotinic excitation of VIPergic interneurons reported in this study may be critical for locally increasing the energy supply in the neocortex during periods of increased neuronal activity. Furthermore, disorders in this homeostatic mechanism for balancing the energy supply with the energy demand may be involved in diseases associated with cholinergic deficits, as indicated by the finding that there is a decrease in cerebral glucose utilization and blood flow in patients with Alzheimer's disease (Eberling et al., 1992; Swerdlow et al., 1994) that can be reversed by increasing cholinergic excitation (Wilson et al., 1991; Parks et al., 1996). The high level of expression of $\alpha 5$ subunits in VIP interneurons may confer a unique pharmacological profile to their nicotinic receptors (Yu and Role, 1998) that could be used to selectively excite this class of neocortical interneurons.

\section{REFERENCES}

Alkondon M, Albuquerque EX (1993) Diversity of nicotinic acetylcholine receptors in rat hippocampal neurons. I. Pharmacological and functional evidence for distinct structural subtypes. J Pharmacol Exp Ther 265:1455-1473.

Angulo MC, Lambolez B, Audinat E, Hestrin S, Rossier J (1997) Subunit composition, kinetic, and permeation properties of AMPA receptors in single neocortical nonpyramidal cells. J Neurosci 17:6685-6696. Boulter J, O'Shea-Greenfield A, Duvoisin RM, Connolly JG, Wada E, Jensen A, Gardner PD, Ballivet M, Deneris ES, McKinnon D (1990) 
$\alpha 3$, $\alpha 5$, and $\beta 4$ : three members of the rat neuronal nicotinic acetylcholine receptor-related gene family form a gene cluster. J Biol Chem 265:4472-4482.

Cauli B, Audinat E, Lambolez B, Angulo M-C, Ropert N, Tsuzuki K, Hestrin S, Rossier J (1997) Molecular and physiological diversity of cortical nonpyramidal cells. J Neurosci 17:3894-3906.

Changeux JP, Bertrand D, Corringer PJ, Dehaene S, Edelstein S, Lena C, Le Novere N, Marubio L, Picciotto M, Zoli M (1998) Brain nicotinic receptors: structure and regulation, role in learning and reinforcement. Brain Res Brain Res Rev 26:198-216.

Chédotal A, Cozzari C, Faure MP, Hartman BK, Hamel E (1994a) Distinct choline acetyltransferase (ChAT) and vasoactive intestinal polypeptide (VIP) bipolar neurons project to local blood vessels in the rat cerebral cortex. Brain Res 646:181-193.

Chédotal A, Umbriaco D, Descarries L, Hartman BK, Hamel E (1994b) Light and electron microscopic immunocytochemical analysis of the neurovascular relationships of choline acetyltransferase and vasoactive intestinal polypeptide nerve terminals in the rat cerebral cortex. J Comp Neurol 343:57-71.

Connor JR, Peters A (1984) Vasoactive intestinal polypeptide-immunoreactive neurons in rat visual cortex. Neuroscience 12:1027-1044.

Cooper E, Couturier S, Ballivet M (1991) Pentameric structure and subunit stoichiometry of a neuronal nicotinic acetylcholine receptor. Nature 350:235-238.

Couturier S, Bertrand D, Matter JM, Hernandez MC, Bertrand S, Millar N, Valera S, Barkas T, Ballivet M (1990) A neuronal nicotinic acetylcholine receptor subunit $(\alpha 7)$ is developmentally regulated and forms a homo-oligomeric channel blocked by $\alpha$-BTX. Neuron 5:847-856.

Eberling JL, Jagust WJ, Reed BR, Baker MG (1992) Reduced temporal lobe blood flow in Alzheimer's disease. Neurobiol Aging 13:483-491.

Eckenstein F, Baughman RW (1984) Two types of cholinergic innervation in cortex, one co-localized with vasoactive intestinal polypeptide. Nature 309:153-155.

Elgoyhen AB, Johnson DS, Boulter J, Vetter DE, Heinemann S (1994) $\alpha 9$ : an acetylcholine receptor with novel pharmacological properties expressed in rat cochlear hair cells. Cell 79:705-715.

Frazier CJ, Rollins YD, Breese CR, Leonard S, Freedman R, Dunwiddie TV (1998) Acetylcholine activates an $\alpha$-bungarotoxin-sensitive nicotinic current in rat hippocampal interneurons, but not pyramidal cells. J Neurosci 18:1187-1195.

Gil Z, Connors BW, Amitai Y (1997) Differential regulation of neocortical synapses by neuromodulators and activity. Neuron 19:679-686.

Gitelman DR, Prohovnik I (1992) Muscarinic and nicotinic contributions to cognitive function and cortical blood flow. Neurobiol Aging 13:313-318.

Granon S, Poucet B, Thinus-Blanc C, Changeux JP, Vidal C (1995) Nicotinic and muscarinic receptors in the rat prefrontal cortex: differential roles in working memory, response selection and effortful processing. Psychopharmacology 119:139-144.

Gray R, Rajan AS, Radcliffe KA, Yakehiro M, Dani JA (1996) Hippocampal synaptic transmission enhanced by low concentrations of nicotine. Nature 383:713-716.

Hendry SH, Jones EG, Beinfeld MC (1983) Cholecystokininimmunoreactive neurons in rat and monkey cerebral cortex make symmetric synapses and have intimate associations with blood vessels. Proc Natl Acad Sci USA 80:2400-2404.

Itakura T, Yokote H, Okuno T, Naka Y, Nakakita K, Kamei I, Nakai K, Imai H, Komai N (1987) Regulation of rCBF by intracortical vasoactive intestinal polypeptide-containing neurons. Immunohistochemical and hydrogen clearance study in rats. J Neurosurg 67:93-96.

Jones S, Yakel JL (1997) Functional nicotinic ACh receptors on interneurones in the rat hippocampus. J Physiol (Lond) 504:603-610.

Kawaguchi Y (1995) Physiological subgroups of nonpyramidal cells with specific morphological characteristics in layer II/III of rat frontal cortex. J Neurosci 15:2638-2655.

Kawaguchi Y, Kubota Y (1996) Physiological and morphological identification of somatostatin- or vasoactive intestinal polypeptide-containing cells among GABAergic cell subtypes in rat frontal cortex. J Neurosci 16:2701-2715.

Kubota Y, Kawaguchi Y (1997) Two distinct subgroups of cholecystokinin-immunoreactive cortical interneurons. Brain Res 752:175-183.

Kubota Y, Hattori R, Yui Y (1994) Three distinct subpopulations of GABAergic neurons in rat frontal agranular cortex. Brain Res 649:159-173.
Lambolez B, Audinat E, Bochet P, Crépel F, Rossier J (1992) AMPA receptor subunits expressed by single Purkinje cells. Neuron 9:247-258.

Le Novere N, Changeux JP (1995) Molecular evolution of the nicotinic acetylcholine receptor: an example of multigene family in excitable cells. J Mol Evol 40:155-172.

Lena C, Changeux JP (1997) Pathological mutations of nicotinic receptors and nicotine-based therapies for brain disorders. Curr Opin Neurobiol 7:674-682.

Luetje CW, Patrick J (1991) Both $\alpha$ - and $\beta$-subunits contribute to the agonist sensitivity of neuronal nicotinic acetylcholine receptors. J Neurosci 11:837-845.

Magistretti PJ (1990) VIP neurons in the cerebral cortex. Trends Pharmacol Sci 11:250-254.

Magistretti PJ, Morrison JH, Shoemaker WJ, Sapin V, Bloom FE (1981) Vasoactive intestinal polypeptide induces glycogenolysis in mouse cortical slices: a possible regulatory mechanism for the local control of energy metabolism. Proc Natl Acad Sci USA 78:6535-6539.

Magistretti PJ, Morrison JH, Shoemaker WJ, Bloom FE (1984) Morphological and functional correlates of VIP neurons in cerebral cortex. Peptides 5:213-218.

McCormick DA, Connors BW, Lighthall JW, Prince DA (1985) Comparative electrophysiology of pyramidal and sparsely spiny stellate neurons of the neocortex. J Neurophysiol 54:782-806.

McGehee DS, Heath MJ, Gelber S, Devay P, Role LW (1995) Nicotine enhancement of fast excitatory synaptic transmission in CNS by presynaptic receptors. Science 269:1692-1696.

Morrison JH, Magistretti PJ, Benoit R, Bloom FE (1984) The distribution and morphological characteristics of the intracortical VIP-positive cell: an immunohistochemical analysis. Brain Res 292:269-282.

Newhouse PA, Potter A, Levin ED (1997) Nicotinic system involvement in Alzheimer's and Parkinson's diseases. Implications for therapeutics. Drugs Aging 11:206-228.

Palma E, Bertrand S, Binzoni T, Bertrand D (1996) Neuronal nicotinic $\alpha 7$ receptor expressed in Xenopus oocytes presents five putative binding sites for methyllycaconitine. J Physiol (Lond) 491:151-161.

Papadopoulos GC, Parnavelas JG, Cavanagh ME (1987) Extensive coexistence of neuropeptides in the rat visual cortex. Brain Res 420:95-99.

Papke RL (1993) The kinetic properties of neuronal nicotinic receptors: genetic basis of functional diversity. Prog Neurobiol 41:509-531.

Papke RL, Boulter J, Patrick J, Heinemann S (1989) Single-channel currents of rat neuronal nicotinic acetylcholine receptors expressed in Xenopus oocytes. Neuron 3:589-596.

Parks RW, Becker RE, Rippey RF, Gilbert DG, Matthews JR, Kabatay E, Young CS, Vohs C, Danz V, Keim P, Collins GT, Zigler SS, Urycki PG (1996) Increased regional cerebral glucose metabolism and semantic memory performance in Alzheimer's disease: a pilot double blind transdermal nicotine positron emission tomography study. Neuropsychol Rev 6:61-79.

Porter JT, Cauli B, Staiger JF, Lambolez B, Rossier J, Audinat E (1998) Properties of bipolar VIPergic interneurons and their excitation by pyramidal neurons in the rat neocortex. Eur J Neurosci 10:3617-3628.

Ramirez-Latorre J, Yu CR, Qu X, Perin F, Karlin A, Role L (1996) Functional contributions of $\alpha 5$ subunit to neuronal acetylcholine receptor channels. Nature 380:347-351.

Roerig B, Nelson DA, Katz LC (1997) Fast synaptic signaling by nicotinic acetylcholine and serotonin 5-HT3 receptors in developing visual cortex. J Neurosci 17:8353-8362.

Role LW, Berg DK (1996) Nicotinic receptors in the development and modulation of CNS synapses. Neuron 16:1077-1085.

Ruano D, Lambolez B, Rossier J, Paternain AV, Lerma J (1995) Kainate receptor subunits expressed in single cultured hippocampal neurons: molecular and functional variants by RNA editing. Neuron 14:1009-1017.

Sanberg PR, Silver AA, Shytle RD, Philipp MK, Cahill DW, Fogelson HM, McConville BJ (1997) Nicotine for the treatment of Tourette's syndrome. Pharmacol Ther 74:21-25.

Sanberg PR, Shytle RD, Silver AA (1998) Treatment of Tourette's syndrome with mecamylamine [letter]. Lancet 352:705-706.

Sargent PB (1993) The diversity of neuronal nicotinic acetylcholine receptors. Annu Rev Neurosci 16:403-443.

Sivilotti L, Colquhoun D (1995) Acetylcholine receptors: too many channels, too few functions. Science 269:1681-1682.

Steinlein OK, Mulley JC, Propping P, Wallace RH, Phillips HA, Sutherland GR, Scheffer IE, Berkovic SF (1995) A missense mutation in the 
neuronal nicotinic acetylcholine receptor $\alpha 4$ subunit is associated with autosomal dominant nocturnal frontal lobe epilepsy. Nat Genet 11:201-203.

Swerdlow R, Marcus DL, Landman J, Kooby D, Frey W, Freedman ML (1994) Brain glucose metabolism in Alzheimer's disease. Am J Med Sci 308:141-144.

Thomson AM, Deuchars J (1994) Temporal and spatial properties of local circuits in neocortex. Trends Neurosci 17:119-126.

Uchida S, Kagitani F, Nakayama H, Sato A (1997) Effect of stimulation of nicotinic cholinergic receptors on cortical cerebral blood flow and changes in the effect during aging in anesthetized rats. Neurosci Lett 228:203-206.

Vidal C, Changeux JP (1993) Nicotinic and muscarinic modulations of excitatory synaptic transmission in the rat prefrontal cortex in vitro. Neuroscience 56:23-32.

Wada E, Wada K, Boulter J, Deneris E, Heinemann S, Patrick J, Swanson LW (1989) Distribution of $\alpha 2, \alpha 3, \alpha 4$, and $\beta 2$ neuronal nicotinic receptor subunit mRNAs in the central nervous system: a hybridization histochemical study in the rat. J Comp Neurol 284:314-335.

Wada E, McKinnon D, Heinemann S, Patrick J, Swanson LW (1990) The distribution of mRNA encoded by a new member of the neuronal nicotinic acetylcholine receptor gene family $(\alpha 5)$ in the rat central nervous system. Brain Res 526:45-53.

Whitehouse PJ, Martino AM, Wagster MV, Price DL, Mayeux R, Atack JR, Kellar KJ (1988) Reductions in $\left[{ }^{3} \mathrm{H}\right]$ nicotinic acetylcholine binding in Alzheimer's disease and Parkinson's disease: an autoradiographic study. Neurology 38:720-723.

Wilson K, Bowen D, Francis P, Tyrrell P (1991) Effect of central cholinergic stimulation on regional cerebral blood flow in Alzheimer's disease. Br J Psychiatry 158:558-562.

Xiang Z, Huguenard JR, Prince DA (1998) Cholinergic switching within neocortical inhibitory networks. Science 281:985-988.

Yaksh TL, Wang JY, Go VL (1987) Cortical vasodilatation produced by vasoactive intestinal polypeptide (VIP) and by physiological stimuli in the cat. J Cereb Blood Flow Metab 7:315-326.

Yu CR, Role LW (1998) Functional contribution of the $\alpha 5$ subunit to neuronal nicotinic channels expressed by chick sympathetic ganglion neurones. J Physiol (Lond) 509:667-681.

Zoli M, Lena C, Picciotto MR, Changeux JP (1998) Identification of four classes of brain nicotinic receptors using $\beta 2$ mutant mice. J Neurosci 18:4461-4472. 